\title{
TINJAUAN KRIMINOLOGIS TERHADAP RESIDIVIS NARKOBA
}

\author{
Julkifli Sinaga \\ Universitas Tarumanagara (UNTAR) Jakarta, Indonesia \\ Email: d7ul.6791@gmail.com
}

\begin{abstract}
Narcotics are very addictive for consumers, and they can be severely addictive. In fact, nothing ever exists in his good name and a match. In jayapura police jurisdiction, residiat reskrim becomes an internal issue. Criminals who commit suicide after birth in prison are not versatile, which they deter, but they become increasingly intelligent and courageous in their fight against them. Once time passes and where criminal officials for opioid offenders are illegitimate, this is the problem. The purpose of this research used to be for empirical legal analysis where the data of the story and literature of the study. Data analysis of deductive analysis of logic in this study. Where the data process is good, starting with general analysis and drawing is equal to the discussion of a path. In jayapura city police jurisdiction, ex-three reasons for drug recidivist criminology: 1) economic factors, 2) environmental factors, and 3) legal factors
\end{abstract}

Keywords: narcotics; recidivist; drug recidivists

\begin{abstract}
Abstrak
Narkotika sangat membuat ketagihan bagi konsumennya, dan mereka dapat menyebabkan kecanduan parah. Bahkan, tidak ada yang pernah dituduh atas tuduhan narkoba dan melakukan kejahatan. Di wilayah hukum Polres Jayapura, residiat narkoba menjadi isu serius. Para penjahat yang bunuh diri setelah dilahirkan di penjara tidak serbaguna, yang membuat mereka jera, tetapi mereka menjadi semakin cerdas dan berani dalam upaya memerangi narkoba mereka. Setelah waktu berlalu dan telah ditentukan bahwa sanksi pidana bagi pelanggar opioid tidak efektif, ini menjadi masalah. Tujuan penelitian ini adalah untuk menganalisis hukum empiris di mana data dikumpulkan melalui wawancara dan tinjauan literatur. Pendekatan analisis data deduktif logika digunakan dalam penelitian ini. Di mana proses peninjauan data dilakukan, dimulai dengan analisis umum dan diakhiri dengan diskusi terperinci. Di wilayah hukum Polres Jayapura Kota, terdapat tiga alasan kriminogenik residiat narkoba: 1) faktor ekonomi, 2) faktor lingkungan, dan 3) faktor penegakan hukum.
\end{abstract}

Kata Kunci: narkotika; residivist; residivawan narkoba

\section{Pendahuluan}

Narkoba atau Napza merupakan singkatan dari Narkotika, Psikotropika dan obatobatan terlarang. Sedangkan istilah Napza adalah singkatan dari Narkotika, Psikotropika dan Zat Adiktif berbahaya lainnya. Narkotika sendiri berasal dari bahasa Inggris

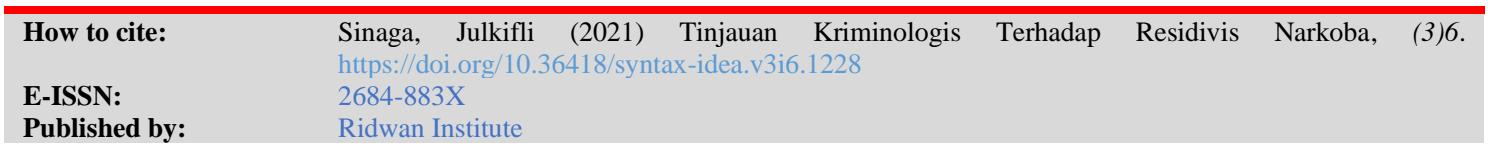


"narcotics" yang arinya obat bius (Oky, 2020). Pemerintah melalui UU Narkotika mengelompokkan Narkotika menjadi tiga golongan, yaitu: Narkotika golongan I, Narkotika golongan II, Narkotika golongan III (Peraturan Menteri Kesehatan Republik Indonesia Nomor 41 Tahun 2017). Namun untuk Narkotika golongan I, sama sekali tidak dapat digunakan bahkan untuk kepentingan kesehatan sekalipun. Narkotika golongan I hanya dapat digunakan dengan jumlah yang terbatas untuk kepentingan pengembangan ilmu pengetahuan dan teknologi serta untuk reagensia diagnostik dan reagnesia laboratorium setelah sebelumnya mendapatkan izin dari Menteri atas rekomendasi Kepala Badan Pengawas Obat dan Makanan (Oky, 2020).

Terdapat 161 jenis narkotika golongan I menurut lampiran Peraturan Menteri Kesehatan Republik Indonesia Nomor 50 tahun 2018. Namun diantara jenis-jenis tersebut, beberapa jenis yang familiar disalahgunakan oleh masyarakat adalah heroin, kokain, daun kokain, opium, ganja, cijing, katinon, MDMDA/ekstasi, dan sabu-sabu (Ramadhan, 2020). Pelaku penyalahgunaan narkoba dapat dipidana, hal tersebut diatur dalam pasal 111 hingga pasal 148 Undang-Undang Narkotika. Jadi kurang lebih terdapat 37 pasal yang mengatur mengenai sanksi-sanksi pidana yang dapat diterapkan dalam tindakan penyalahgunaan narkotika.

PerJanuari hingga Agustus 2020, Polres Jayapura Kota saja sudah berhasil mengamankan 42 orang tersangka kasus narkoba (Jayapura, 2020). Kemudian BNN Provinsi Papua juga berhasil mengungkap 9 kasus narkoba di wilayah Papua pada periode yang sama (Nainggolan, 2018). Narkotika sesungguhnya sangat menimbulkan candu bagi penggunanya, narkotika mampu menimbulkan candu yang sangat besar. Bahkan tak jarang pelaku penyalahgunaan narkoba yang sudah dipidana dan mendapatkan hukuman kurungan kembali melakukan pengulangan tindak pidana (Sinaga, 2021).

Pengulangan tindak pidana atau disebut juga sebagai residivis adalah pengulangan suatu tindak pidana oleh pelaku yang sama, yang mana tindak pidana yang dilakukan sebelumnya telah dijatuhi pidana dan berkekuatan hukum tetap, serta pengulangan terjadi dalam jangka waktu tertentu (Hutabarat, 2020). Pelaku residivis narkoba merupakan salah satu masalah serius yang terjadi di wilayah hukum Polresta Jayapura. Para pelaku penyalahgunaan narkoba setelah ditahan di lapas tidak lantas menjadikan mereka jera, namun terkesan justru semakin lihai dan semakin berani dalam mengedarkan narkoba. Hal tersebut yang lantas menjadi pertanyaan, mengapa setelah ditahan dan diputuskan hukuman pidana para tahanan narkotika tidak jera.

Melalui kebijakan pemerintah melalui Kementrian Hukum dan HAM (Hak Asasi Manusia) dalam melakukan program asimilasi melalui Peraturan Menteri Hukum dan Hak Asasi Manusia Nomor 10 tahun 2020, banyak narapidana kasus penyalahgunaan narkotika yang akhirnya dibebaskan melalui program asimilasi. Namun baru sebentar meghirup udara bebas, narapidana tersebut kembali ditangkap oleh pihak Polisi karena melakukan kesalahan terkait penyalahguanaan narkoba kembali. 


\section{Metode Penelitian}

Penelitian ini menggunakan pendekatan analisis data deduktif logika digunakan dalam penelitian ini. Di mana proses peninjauan data dilakukan, dimulai dengan analisis umum dan diakhiri dengan diskusi terperinci. Di wilayah hukum Polres Jayapura Kota, terdapat tiga alasan kriminogenik residiat narkoba: 1) faktor ekonomi, 2) faktor lingkungan, dan 3) faktor penegakan hukum (Laksono, 2010).

\section{Hasil dan Pembahasan}

A. Faktor Kriminogen yang Memengaruhi Pelaku Residivis Narkoba di Polres Jayapura

Faktor kriminogen adalah suatu faktor yang menyebabkan munculnya suatu tindak pidana baru. Dalam kasus tindak pidana narkotika ini, bukan memunculkan suatu tindak pidana baru, hanya saja menjadikan pelaku tindak pidana semakin ahli dalam melaksanakan aksinya. Hal tersebut terjadi karena ketika berada di lapas, para narapidana akan bertemu banyak narapidana lain yang bisa jadi sudah lebih ahli dan lebih besar lagi. Jadi di lapas bukannya bertaubat dan berfikir untuk berhenti, mereka malah belajar untuk menjadi lebih besar lagi. Ketika dahulu dia merupakan pemakai narkoba, maka ketika keluar dari lapas dia bisa menjadi pengedar narkoba atau bahkan bandar (Syamsu \& SH, 2015).

Setelah melakukan penelitian dan mewawancarai narasumber dalam penelitian ini, peneliti menemukan bahwa setidaknya terdapat tiga hal yang menjadi faktor kriminogen bagi pelaku residivis narkoba di wilayah hukum Polres Jayapura Kota, yaitu: 1) Faktor Ekonomi; 2) Faktor Lingkungan; dan 3) Faktor Penegakan Hukum. Dimana menurut peneliti ketiga faktor tersebut memiliki andil yang kuat dalam menjadikan seorang narapidana narkoba menjadi seorang residivis narkoba.

1) Faktor Ekonomi

Dalam wawancara dengan saudara F yang dilaksanakan pada 23 Desember 2020 di sel BNNP, F menyebutkan bahwa dirinya memutuskan untuk kembali melakukan tindak pidana narkotika (residivis) karena keterdesakan masalah ekonomi. Saat itu F bebas karena memperoleh hak asimilasi covid-19 yang dimaksanakan oleh Kemenkumham dalam Rangka Pencegahan dan Penanggulangan Penyebaran Covid-19 yang tertuang dalam Perkemenkumham 10/2020.

Setelah bebas $\mathrm{F}$ berkeinginan untuk kembali ke kampung halamannya yang berada di luar Provinsi papua, namun hal tersebut tidak mungkin dilaksanakan karena Papua yang menerapkan lockdown. Hingga akhirnya $\mathrm{F}$ memutuskan untuk menetap kembali di Papua. Namun diakibatkan pandemi dan banyak dari sektor usaha yang tutup sehingga $\mathrm{F}$ tidak mendapatkan pekerjaan, dimana $\mathrm{F}$ membutuhkan pekerjaan untuk membiayai hidupnya. Hingga akhirnya $F$ memutuskan untuk menerima ajakan temannya untuk 'menjaga' barang temannya yang berupa narkotika. Hingga $F$ ditangkap oleh pihak berwajib dan kembali menjadi tahanan dan menjadi residivis.

Narapidana merupakan anggota dari masyarakat umum yang memiliki hak dan kewajiban sebagaimana warga negara lainnya, dikarenakan perlakuannya 
dalam kehidupan sehari-hari telah melakukan kesalahan yaitu melanggar hukum yang berlaku, maka untuk sementara waktu dimasukkan kedalam Lembaga Pemasyarakatan dan akan kehilangan kemerdekaannya dalam waktu tertentu (Kualitas Hidup Pada Narapidana di Lembaga Pemasyarkatan Klas IIA Wanita Tangerang, Maret 2015).

Konsekuensi dari kesalahan yang dilakukan oleh narapidana, maka yang bersangkutan dimasukkan ke dalam Lapas untuk waktu yang sudah ditentukan. Dimana dalam UU Pemasyarakatan Pasal 1 Ayat 3 dijelaskan bahwa Lembaga Pemasyarakatan yang selanjutnya disebut Lapas adalah tempat untuk melaksanakan pembinaan Narapidana dan Anak didik pemasyarkatan. Lapas sebagai tempat pembinaan dengan tujuan agar narapidana dapat kembali menjadi warga masyarakat yang baik, yang menyadari segala kesalahannya serta dapat kembali ke dalam masyarakat dengan menjadi manusia yang baik (Utami \& Indonesia, 2017).

Tujuan keberadaan narapidana di Lapas adalah untuk dibina dengan tujuan agar narapidana dapat kembali menjadi warga masyarakat yang baik. Kesiapan narapidana untuk masuk kembali ke dalam masyarakat tentunya tidak mengesampingkan akan kesiapan narapidana dalam memenuhi kebutuhan hidupnya. Hal tersebut berkaitan dengan kesiapan dari narapidana dalam aspek ekonomi ketika sudah dinyatakan bebas dan siap untuk kembali ke masyarakat. Dalam upaya pemenuhan dari kesiapan ekonomi tersebut, Lapas sebagai Lembaga tempat pembinaan narapidana dibina dan dibimbing memiliki program pembinaan yang berkaitan dengan hal tersebut. program pembinaan tersebut merupakan satu dari dua fokus pembinaan yang terdapat dalam program pembinaan Lapas, yaitu pembinaan kemandirian. Dimana dalam program pembinaan kemandirian narapidana akan diajarkan suatu skill/ keterampilan yang diharapkan nanti berguna ketika yang bersangkutan sudah bebas (Wawancara dengan Kalapas narkotika Doyo, 2020).

Namun nyatanya pembinaan keterampilan tersebut tidak bisa diaplikasikan secara optimal, karena saudara F seorang residivis yang sudah tiga kali masuk ke dalam Lapas dengan kasus tindak pidana yang sama belum pernah mendapatkan pembinaan kemandirian yang dimaksud. Mengkonfirmasi hal tersebut dengan pernyataan Kalapas, hal tersebut terjadi karena terbatasnya anggaran terkait penyelenggaraan pembinaan kemandirian tersebut.

2) Faktor Lingkungan

Lapas Narkotika Kelas II A Doyo masuk ke dalam kategori Lapas Khusus, karena pada Lapas Narkotika Doyo khusus untuk melakukan pembinaan bagi narapidana dengan kasus pelanggaran tindak pidana narkotika. Pembagian Lapas Khusus dan Lapas Umum dapat ditemukan dalam sistem Lapas di Indonesia, dimana pembagian lapas tersebut dipahami juga dengan pengklasifikasian narapidana. Klasifikasi narapidana adalah pengelompokan narapidana berdasarkan pada kriteria tertentu yang sesuai dengan kepentingannya. Hal tersebut dilakukan untuk memudahkan proses pencatatan data dari masing- 
masing kelompok. Pengelompokan tersebut dilakukan berdasarkan umur, jenis kelamin, lama pidana, jenis kejahatan dan kriteria lainnya yang sesuai dengan kebutuhan dan perkembangan pembinaan (Online, 2021).

Dalam tindak pidana penyalahgunaan narkotika terdapat istilah pemakai narkotika, yaitu para pecandu narkotika dan penyalahgunaan narkotika. Kemudian terdapat juga pengedar narkotika, dimana yang termasuk dalam pengedar narkotika adalah pihak yang memproduksi narkotika, pihak yang melakukan ekspor dan impor narkotika dengan cara yang bertentangan dengan hukum, pihak yang melakukan pengangkutan dan transit narkotika dengan cara yang bertentangan dengan hukum, pihak yang melakukan peredaran narkotika secara illegal dan prekusor narkotika (UU Narkotika).

Di dalam Lapas Doyo semua narapidana pelaku tindak pidana penyalahgunaan narkotika tersebut berada di dalam Lapas yang sama. Jadi tidak dapat perbedaan antara sel pengedar dengan pemakai narkotika, semuanya berada di dalam sel yang sama. Hal tersebut disampaikan oleh Saudara F ketika wawancara di sel BNN, dimana hal tersebut juga dibenarkan oleh Kalapas. Hal tersebut sebenarnya sangat rentan dalam menimbulkan suatu kesempatan bagi para narapidana yang berada di Lapas Doyo untuk bisa saling berkomunikasi antara narapidana pemakai narkotika dengan pengedar narkotika. Dimana pemakai narkoba yang sebelumnya hanya memakai dan menyalahgunakan narkotika saja, kemudian seperti mendaptkan peluang baru untuk menjual atau mengedarkan barang terlarang tersebut.

Hal tersebut kemudian bisa menjadi faktor kriminogen yang menjadikan para narapidana melakukan tindak pidana yang sama lagi ketika nantinya dia sudah keluar dari Lapas. Hal tersebut dikarenakan para narapidana yang masuk ke dalam Lapas akan semakin mengatahui seluk beluk serta informasi terkait pengedaran narkotika. Ketika bertemu dengan yang lebih ahli, para narapidana tersebut akan saling bertukar informasi dan justru menjadi semakin ahli ketika berada di Lapas. Sehingga probabilitas para narapidana tersebut menjadi seorang residivis akan semakin besar.

Suwarto memberikan pandangan bahwa penggolongan narapidana itu perlu dilakukan, baik dilihat dari segi keamanan dan pembinaan serta menjaga pengaruh negatif yang dapat berpengaruh terhadap narapidana lainnya. Suwarto juga manambahkan bahwa jenis kejahatan juga merupakan salah satu jenis karakteristik ide individualisasi dalam pembinaan narapidana. Untuk itu perlu dilakukan pemisahan-pemisahan narapidana berdasarkan pada jenis kejahatannya. Hal ini dilakukan untuk menghilangkan prisonisasi atas narapidana (Utami \& Indonesia, 2017).

Ketika peneliti menanyakan kepada Kalapas, Kalapas juga membenarkan terkait adanya kemungkinan narapidana yang masuk ke Lapas akan menjadi lebih ahli ketika keluar dari Lapas. Dikarenakan kemungkinan bertemu bandar yang lebih besar lagi, dan di dalam sel semua disatukan dalam satu sel yang sama.Peneliti merasa bahwa solusi yang tepat untuk menghindari pertukaran 
informasi dan menjadikan narapidana tersebut menjadi semakin ahli adalah dengan melakukan pemisahan sel antara narapidana tindak pidana pemakai narkotika dengan narapidana tindak pidana pengedar narkotika. Hal itu dilakukan guna meminimalisir terjadinya pertukaran informasi atau menghindari kesepakatan-kesepakatan yang mungkin saja terjadi (Nursiyah, 2017).

3) Faktor Penegakan Hukum

Lembaga pemasyarakatan sebagai ujung tombak dari pelaksanaan asas pengayoman merupakan tempat untuk mencapai tujuan dari Lembaga Pemasyarakatan dengan melakukan bimbingan dan pembinaan melalui Pendidikan, rehabilitasi dan integrasi (Walukow, 2013). Maka Lapas adalah tempat pembinaan bagi narapidana dan anak dengan tujuan agar narapidana dan anak menyadari segala kesalahannya dan setelah bebas, narapidana dan anak bisa kembali lagi ke dalam masyarakat dengan keadaan yang lebih baik lagi.

Proses pembinaan dan bimbingan di lapas masuk ke dalam kategori sistem pemasyarakatan. Dimana menurut UU Pemasyarakatan Pasal 1 Ayat 2 bahwa, suatu tatanan mengenai arah dan batas serta cara pembinaan Warga Binaan Pemasyarakatan beradasarkan Pancasila yang dilaksanakan secara terpadu antara pembina, yang dibina, dan masyarakat untuk meningkatkan kualitas Warga Binaan Pemasyarakatan agar menyadari kesalahan, memperbaiki diri, dan tidak mengulangi tindak pidana sehingga dapat diterima kembali oleh lingkungan masyarakat, dapat aktif berperan dalam pembangunan, dan dapat hidup secara wajar sebagai warga yang baik dan bertanggungjawab (Maryani, 2015).

Dimana sistem pemasyarakatn diselenggarakan dalam rangka membentuk Warga Binaan Pemasyarakatan agar menjadi manusia seutuhnya, menyadari kesalahan, memperbaiki diri, dan tidak mengulangi tindak pidana sehingga dapat diterima kembali oleh lingkungan masyarakat, aktif dalam pembangunan, dan dapat hidup secara wajar sebagai warga yang baik dan bertanggung jawab. Hal tersebut seperti yang tertera pada Pasal 2 UU Kemasyarakatan. Kemudian ditambahkan pada Pasal 3 UU Pemasyarakatan bahwa Sistem Pemasyarakatan berfungsi menyiapkan Warga Binaan Pemasyarakatan agar dapat berintegrasi secara sehat dengan masyarakat, sehingga dapat berperan kembali sebagai anggota masyarakat yang bebas dan bertanggung jawab.

Terkait terjadinya residivis narkoba dimana residivis tersebut sbeelumnya sudah mendapatkan proses pembinaan dan bimbingan di Lapas Narkotika Doyo, maka bisa dikatakan bahwa Lapas Narkotika Doyo sebagai ujung tombak dari penegakan hukum terkait pembinaan narapidana narkoba tidak bekerja secara maksimal. Jika merujuk kepada regulasi yang ada, seharusnya pembinaan di lapas Narkotika Doyo dapat dilaksanakan secara maksimal. Namun kenyataannya hal tersebut tidak terjadi, beradasarkan hasil wawancara peneliti dengan Kalapas, hal tersebut diakibatkan terbenturnya pihak Lapas dengan anggaran yang terbatas. Sehingga proses pelaksanaan pembinaan dan pembimbingan tidak dapat dilaksanakan secara optimal. 
B. Menimbulkan Efek Jera Bagi Pelaku Residivis Narkoba di Polres Jayapura

Narapidana narkotika sangat rentan untuk kembali melakukan tindak pidana yang sama yaitu terkait penyalahgunaan narkotika. Dalam upaya untuk menimbulkan efek jera bagi pelaku residivis narkoba di Jayapura harus menjadi perhatian khusus bagi pihak-pihak yang terkait, terutama pihak Lapas sebagai institusi pemerintah yang bertugas dalam proses pembinaan dan bimbingan bagi para narapidana. Dikarenakan mengandung zat adiktif yang mengakibatkan kepada kecanduan, pengguna narkotika sangat rentan untuk kembali menggunakan narkotika. Maka upaya yang dilakukan adalah dengan memotong hubungan yang memungkinkan pelaku tindak pidana narkotika kembali masuk ke jaringan narkotika. Hal tersebut bisa dimulai dari mengubah lingkungannya, atau mensterilisasi lingkungannya. Terutama lingkungan Lapas sebagai lingkungan bagi narapidana pelaku tindak pidana narkotika.

Pada dasarnya sudah terdapat regulasi yang mendukung untuk memutus hubungan jaringan narkotika di dalam Lapas, hal tersebut berkaitan dengan keberadaan kelas-kelas di dalam Lapas. Seperti maximal security, medium security, dan minimal security. Namun dalam prakteknya hal seperti itu tidak ada di Lapas Narkotika Doyo, sebagai Lembaga Pemasyarakatan bagi narapidana penyalahgunaan narkotika di wilayah Jayapura. Namun menurut Kalapas, keberadaan dari Lapas dengan maximal security, medium security, dan minimal security hanya terdapat di Lapas umum, bukan di Lapas khusus seperti Lapas Narkotika Kelas II A Doyo. Kalapas menambahkan bahwa di Lapas Doyo. Walau bukan masuk lapas maxiumum security, namun dari pusat sudah terdapat instruksi bahwa jika terdapat narapidana yang sangat tidak kooperatif maka akan segera dilaporkan ke pusat dan akan dilakukan penindakan terkait pengangkutan ke lapas maximum security (Wawancara dengan Kalapas narkotika Doyo, 2020).

Pada lapas Narkotika Doyo jika terdapat narapidana yang membuat masalah atau tidak kooperatif, maka akan dimasukkan ke sel. Dalam ketentuan, narapidana tersebut akan berada di sel selama 6 (enam) hari. Namun jika ternyata masih membangkang dan masih tidak kooperatif, maka akan ditambah lagi hingga satu bulan. Setelah itu dia akan keluar, kemudian hak-haknya akan dicabut, itu merupakan salah satu tindakan yang dilakukan. Karena di Lapas adalah tempat pembinaan (Wawancara dengan Kalapas narkotika Doyo, 2020). Maka dari itu peneliti mengusulkan penting untuk melakukan pengkelasan berdasarkan pada tindak pidana yang dilakukan oleh narapidana narkotika, jadi kelas pemakai tidak digabungkan dengan kelas pengedar. Hal tersebut dirasa bisa meminimalisir persebaran informasi dan terbentuknya komunikasi antara pemakai dengan pengedar, dan diharapkan dapat memotong rantai jaringan narkotika di dalam Lapas.

Narapidana pemakai bisa jadi menjadi lihai ketika bertemu dengan narapidana pengedar. Kemudian narapidana bandar bisa saja justru bertemu kaki tangan baru sebagai peredar ketika bertemu dengan narapidana pengedar. Maka dari itu, perlu dilakukan pengelompokan sel sehingga para narapidana tersebut tidak saling bertemu atau berkomunikasi. Hal tersebut juga sejalan dengan pemikiran Suwarto 
memberikan pandangan bahwa penggolongan narapidana itu perlu dilakukan, baik dilihat dari segi keamanan dan pembinaan serta menjaga pengaruh negatif yang dapat berpengaruh terhadp narapidana lainnya.

Pelaku tindak pidana penyalahgunaan narkotika di Papua akan dibina dan dibimbing di Lapas Doyo, dimana Lapas Doyo merupakan Lapas Khusus yang menangani narapidana dengan kasus penyalahgunaan narkotika. Dalam proses pembinaan yang dilakukan oleh Lapas terdapat dua program pembinaan, yaitu pembinaan kepribadian dan pembinaan kepribadian kemandirian. Program pembinaan kepribadian mendidik narapidana bagaimana untuk bisa mencintai NKRI, memiliki wawasan kebangsaan yang bagus, dan pemahaman akan Pancasila (Wawancara dengan Kalapas narkotika Doyo, 2020).

Salah satu bagian dari program pembinaan kepribadian adalah pembinaan keagamaan. Dalam pembinaan keagamaan, narapidana akan dibina untuk patuh dan tunduk terhadap aturan-aturan agama yang dianutnya. Karena Kalapas beranggapan ketika narapidana sudah tunduk dan patuh terhadap aturan-aturan agama yang dianutnya, maka narapidana tersebut akan mengikuti peraturan negara (Wawancara dengan Kalapas narkotika Doyo, 2020). Sedangkan program pembinaan kemandirian adalah program yang melatih para narapidana agar memilik skill/ kemampuan. Dimana skill/ kemampuan ini diharapkan dapat memberikan manfaat ketika yang bersangkutan sudah bebas. Harapannya dengan skill/ kemampuan yang sudah diperoleh selama di Lapas, yang bersangkutan bisa menjadi mandiri ketika sudah kembali ke tengah-tengah masyarakat.

Dalam melakukan program pembinaan kemandirian, Lapas melakukan kerjasama dengan kedinasan atau perusahaan. Kegiatan terbaru Lapas Narkotika Doyo melakukan Kerjasama dengan Dinas Pertanian, dimana para narapidana diajarkan bagaimana cara mengelola tanah. Bisa dengan bertani atau hal yang lainnya. Kemudian narapidana juga diajarkan bagaimana menjual hasil tani tersebut, dan hal itu langsung dipraktekkan. Harapannya dengan mengikuti pelatihan-pelatihan tersebut akan membangun kemampuan/ skill dari narapidana, sehingga ketika sudah keluar dari lapas pengetahuan terkait keterampilan/ skill tersebut dapat dipraktekkan. Untuk kemudian digunakan sebagai mata pencaharian baru ketika sudah kembali ke tengah-tengah masyarakat.

Menurut penjelasan Kalapas, program pembinaan kepribadian belum berjalan dengan optimal, dan hal tersebut juga dialami hampir oleh semua Lapas. Dikarenakan hal tersebut masih terkendala di beberapa hal. Begitu juga dengan pembinaan kemandirian, hal tersebut belum bisa dilaksanakan secara optimal, dikarenakan keterbatasan anggaran yang dimiliki oleh pihak Lapas. Padahal menurut hemat peneliti keberadaan bimbingan kemandirian ini sangat memiliki efek yang besar bagi para narapidana, karena hal tersebut berkaitan dengan kesiapan mereka setelah keluar dari Lapas.

Terkait dengan yang disampaikan Kalapas dalam wawancara yang dilakukan di Lapas Doyo, terkait pembinaan kemandirian bahwa tidak semua narapidana mendapatkan pembinaan kemandirian. Saudara F sebagai residivis narkoba yang 
sudah masuk Lapas sebanyak tiga kali dan mengatakan bahwa selama tiga kali masuk Lapas Doyo, dirinya belum pernah mendapatkan pembinaan kemandirian seperti yang disampaikan Kalapas. Sejalan dengan yang disampaikan oleh F, saudara I yang juga merupakan seorang residivis narkoba juga mengatakan bahwa dirinya belum pernah mendapatkan pembinaan kemandirian tersebut, bahkan ketika dia akan dibebaskan dari Lapas (Residivis, 2020). Karena berdasarkan penjelasan Kalapas bahwa syarat penerima pembinaan kemandirian tersebut adalah narapidana yang akan bebas dari Lapas.

Pada dasarnya program bimbingan yang dimiliki oleh Lapas sudah sangat mumpuni dalam proses bimbingan dan pembinaan bagi narapidana narkotika, namun kendalanya terdapat pada pelaksanaanya. Pelasksanaan dari program-program bimbingan tersebut tidak terlaksana sebagaimana mestinya. Dan menurut Kalapas, hal tersebut terkendala dengan anggaran yang ada.

Lembaga Pemasyarakatan merupakan bagian dari proses penegakan hukum. Hal tersebut seperti yang tertera pada penjelasna Pasla 8 Ayat 1 UU Kemasyarakatan yang mengatakan bahwa Pemasyarakatan merupakan bagian akhir dari sistem pemidanaan dalam tata peradilan pidana adalah bagian integrasi dari tata peradilan terpadu (integrated criminal justice system). Dengan demikian, pemasyarkaatan baik ditinjau dari sistem, kelembagaan, cara pembinaan, dan petugas pemasyarakatan, merupakan bagian yang tak terpisahkan dari satu rangkaian proses penegakan hukum.

Susanto berpendapat bahwa tujuan dari pembinaan dalam pemasayrakatan, dimana hal tersebut dapat dibagi ke dalam tiga hal yaitu:

a. Setelah keluar dari Lapas yang bersangkutan tidak lagi melakukan tindak pidana;

b. Menjadi manusia yang berguna, berperan aktif dan kreatif dalam membangun bangsa dan negaranya; dan

c. Mampu mendekatkan diri kepada Tuhan Yang Maha Esa dan mendapatkan kebahagiaan dunia maupun di akhirat (Susanto, 2011).

Jika Lapas adalah Lembaga akhir dari lembaga-lembaga yang berperan dalam proses penegakan hukum, maka sudah selayaknya Lapas memiliki peran yang besar dalam menentukan arah dari narapidana ke depannya. Apakah setelah bebas dari Lapas narapidana akan bisa masuk kembali ke dalam masyarkat, atau justru sebaliknya menjadi residivis.

\section{Kesimpulan}

Terdapat tiga faktor kriminogen yang memengaruhi pelaku tindak pidana narkotika Kembali mengulangi kejahatannya (residivis), yaitu: 1) Faktor ekonomi; 2) Faktor lingkungan; 3) Faktor penegakan hukum. Lapas Narkotika Kelas II A Doyo merupakan tempat pembinaan bagi narapidana narkotika yang memiliki tujuan untuk melakukan pembinaan dan bimbingan bagi narapidana tindak narkotika, sehingga narapidana menyadari kesalahannya dan bertaubat. Lapas adalah tempat bagi 
narapidana mendapatkan bimbingan dan pembinaan sehingga narapidana siap kembali untuk menjadi bagian dari masayrakat.

Dalam proses pembinaan dan bimbingan Lapas Doyo memiliki dua program pembinaan, yaitu pembinaan kepribadian yang mencakup di dalamnya pembinaan keagamaan dan pembinaan kemandirian. Pelaksanaan pembinaan baik kepribadian dan kemandirian belum dapat dilaksanakan di Lapas Doyo, hal tersebut karena terkendala akan sarana praarana dan anggaran. Lapas merupakan Lembaga akhir dari lemabaglembaga yang berperan dalam proses penegakan hukum terkait tindak pidana narkotika, terkait akan hal itu maka sudah selayaknya Lapas memiliki peran yang besar dalam menentukan arah dari narapidana ke depannya. Apakah setelah bebas dari Lapas narapidana akan bisa masuk kembali ke dalam masyarkat, atau justru sebaliknya menjadi residivis. 


\section{BIBLIOGRAFI}

Hutabarat, Agustin L. (2020). "https://www.hukumonline.com/klinik/detail/ulasan/lt529 1e21f1ae59/seluk-beluk-residivis/ (15 Agustus 2020).

Laksono, Dandhy Dwi. (2010). Jurnalisme investigasi. Kaifa. Google Scholar

Maryani, Desy. (2015). Faktor-faktor penyebab tidak tercapainya tujuan pemidanaan lembaga pemasyarakatan di Indonesia. Jurnal Hukum Sehasen, 1(1), 1-24. Google Scholar

Nainggolan, Poltak Partogi. (2018). Aktor non-negara: kajian implikasi kejahatan transnasional di Asia Tenggara. Yayasan Pustaka Obor Indonesia. Google Scholar

Nursiyah, N. (2017). Pemberdayaan Narapidana Melalui Pengembangan Agribisnis Sayuran Di Lembaga Pemasyarakatan Wanita Kelas Ii A Way Hui Bandar Lampung. UIN Raden Intan Lampung. Google Scholar

Oky. (2020). “Apa itu Narkoba” (On-Line), tersedia di. Retrieved from http://puspensos.kemsos.go.id/apa-itu-narkoba.

Online, Hukum. (2021). Penggolongan Penempatan Narapidana dalam Satu Sel Lapas.

Peraturan Menteri Kesehatan Republik Indonesia Nomor 41 Tahun 2017. (2017). Perubahan Penggolongan Narkotika.

Ramadhan, Karunia. (2020). “Kenali Golongan dan Jenis Narkotika” (On-Line).

Sinaga, Julkifli. (2021). Tinjauan Kriminologis Terhadap Residivis Narkoba (Studi Kasus Terhadap Nara Pidana yang Memperoleh Hak Asimilasi Kemenkumham Tahun 2020). Universitas Tarumanagara. Google Scholar

Susanto, I. S. (2011). Kriminologi. Yogyakarta. Genta Publishing. Google Scholar

Syamsu, Muhammad Ainul, \& SH, M. H. (2015). Pergeseran turut serta melakukan dalam ajaran penyertaan: Telaah kritis berdasarkan teori pemisahan tindak pidana dan pertanggungjawaban pidana. Kencana. Google Scholar

Utami, Penny Naluria, \& Indonesia, HAMR. (2017). Keadilan Bagi Narapidana di Lembaga Pemasyarakatan. J. Penelit. Huk. e-ISSN, 2579, 8561. Google Scholar

Walukow, Julita Melissa. (2013). Perwujudan Prinsip Equality Before The Law Bagi Narapidana Di Dalam Lembaga Pemasyarakatan Di Indonesia. Lex et Societatis, 1(1). Google Scholar 
Julkifli Sinaga

Wawancara dengan Kalapas narkotika Doyo. (2020). Wawancara dengan Kalapas narkotika Doyo.

Copyright holder :

Julkifli Sinaga (2021)

First publication right :

Jurnal Syntax Idea

This article is licensed under:

(c) $\ominus_{\mathrm{EY}} \ominus_{\mathrm{ND}}$ 